\title{
The Odyssey of 'Ajamī and the Swahili People
}

\author{
John Mugane \\ Harvard University \\ mugane@fas.harvard.edu
}

\begin{abstract}
This paper takes a look at the odyssey of the Arabic script in Swahili hands. It shows how the distinction between the Arabic script and Swahili 'Ajamī constitutes a hyphen whose meaning is saturated with the story of Swahili society and language. The hyphen represents a non-trivial record of Swahili agency as innovative users, authors, transcribers, translators, and interpreters of the Arabic script enlarged its use and versatility as a viable medium to write Swahili, a Bantu language. The paper identifies as resilience Swahili efforts to sustain the use of the unmodified Arabic script alongside the enriched one. The Swahili wrote because they were compelled to write, everyone in their dialect, with content not divorced from script. The Swahili 'Ajamī record is a bonafide source and terminus of Africa's knowledge.
\end{abstract}

\section{Keywords}

Swahili - 'Ajamī script - Tendi - innovation - enrichment - transliteration translation - Africa's sources of knowledge - literary tradition - Swahili civilization

\section{Introduction}

Writing Swahili in the Arabic script is an old phenomenon that is strongly linked to Islam, the faith that the Swahili have professed for centuries, and a faith whose observance demands literacy in Arabic. Like all other Muslims around the world, once the Swahili became literate, they used the Arabic script to write without limitation, though privileging religious topics over secular ones. Like the expression InshäAllah or its Swahili rendition Mwenyezi Mungu akitujalia (God Willing), which Muslims append to virtually every expressed human endeavor and aspiration, Swahili secular writings often have the aura of religion as they are enclosed in brackets of Islamic doxologies. These, 
though sometimes formulaic, are seldom rushed and constitute a deliberate profession of Islam. With these doxologies both the writer and the document claim membership to the larger community of Muslims who are called upon as the audience targeted as readers and hearers, as done in the great Utendi Swahili narrative poetry tradition as well as in small personal notes on mundane issues.

If there ever was a reason why Swahili was once thought to be of Arabic, ${ }^{1}$ rather than African origin it was the script that the Swahili used which is peppered by the seemingly high percentages of Arabic words in the language, especially in religion, commerce, nautical terminology. Though available in impressive numbers in Swahili, Arabic words pale in comparison to the Bantu ones. Swahili "is not atypical either linguistically or sociolinguistically" when compared to the surrounding Bantu languages. However, it "developed out of a very specific Bantu matrix that of the Northeast Coast Bantu." It follows then that writing Swahili in the Arabic script is to develop a way of writing Bantu languages more generally.

Swahili in the Arabic script exists in two forms. One is the use of Arabic script without modification. The other is the use of an enriched Arabic script ('Ajamī). In the unmodified case, the Bantu language, Swahili, is subjected to Arabic script without violating Arabic writing conventions. In the modified case, the script is enriched to accommodate Bantu sound representation. As such, it stands as a historical rebuke of the colonial claim about the inadequacy of the Arabic script to write Swahili. Neither approach has yielded to the other even in the writings of individual scribes, though the unmodified script seems to be quite dominant.

This paper takes a look at the odyssey of the Arabic script in the hands of Swahili authors and scribes of 'Ajamì texts, the enrichers and users to whom we owe a great intellectual debt for the preservation and expansion of the Swahili intellectual tradition. I examine the following two aspects: (1) the ambivalence of Swahili scribes to sustain the use of the standard Arabic script alongside the 'Ajamī, and (2) the eye opening witness of the Swahili 'Ajamī record as a great source and terminus of knowledge. There is something transformative about 'Ajamì for it brings the realization that the verbal aesthetic is literature. The written record brings out two points in the study of Africa, that an "un-writing Africa" is a myth and that the high quality of products in the Swahili literary

1 Alamin M. Mazrui and Ibrahim N. Shariff, The Swahili Idiom and Identity of an African People, Trenton, New Jersey, Africa World Press, 1994.

2 Thomas J. Hinnebusch, "What Kind of Language Is Swahili?", Afrikanistishe Arbeitspapiere, 47 (1996), pp. 73-95. 
tradition lead us to recognize "as false the divide between the oral and written works of Swahili"3 and elsewhere in Africa for they point to a literary tradition developed long before modern pens are put to paper. I end the paper at the point where the colonial era hijacked the writing system and transliterated the Swahili literary tradition almost into oblivion, and moved the center of Swahili scholarship to Europe.

\section{The Swahili Record in Arabic}

The Swahili literary tradition is impressive. According to O'Fahey, Swahili is "the Islamic African language with the most highly developed literary tradition, inviting comparison, particularly in regard to its poetry, with Persian (Iran), Urdu (India) and Turkish." 4 While not enough is known of 'Ajamī writings throughout Africa to warrant such comparisons between Swahili and other languages, especially given recently uncovered Wolof, Hausa, Fuuta Jalon Pular and other 'Ajamī documents across Africa, ${ }^{5}$ we can say that many 'Ajamī literatures stand on their own merit and that Swahili kept company with the best 'Ajamì traditions in Africa and the world until the disruption ushered in by the colonial era beginning in the 1850 s.

In the Swahili literary tradition there are at least 300 known tendi (epic poems) from the eighteenth century to the early twentieth century, but of these only 6 have been properly edited and translated. Some of them include 5,000 four line stanzas and the longest tend $i$ is the one dealing with the last moments of Prophet Muhammad, which comprises 45,000 quatrains. ${ }^{6}$ The Institute of Kiswahili Research at the University of Dar es Salaam holds the largest collection of 4,000 items from the late 1950s and early 1960s gathered by John W.T. Allen; and there are some 600-700 manuscripts that are held at the departments of Antiquities, Archives, and Museums in Zanzibar. ${ }^{7}$ There are major collections of Swahili manuscripts in Germany and at the School of Oriental and African Studies (sOAS) in London. ${ }^{8}$

3 John Mugane, The Story of Swahili, Ohio University Press, 2015, p. 12.

4 Sean R. O'Fahey, "Arabic Literature in the Eastern Half of Africa," in The Meanings of Timbuktu, eds. Shamil Jeppie and Souleyemane B. Diagne, CODESRIA/HSRC, 2008, p. 416.

5 See African Ajami Library (http://dcommon.bu.edu/handle/2144/1896); Africa's Sources of Knowledge Digital Library-ASK-DL (http://www.ask-dl.fas.harvard.edu/); and Endangered Archives Programme (http://eap.bl.uk/database/collections.a4d).

6 See O’Fahey, “Arabic Literature," pp. 333-334.

7 Ibid.

8 Ibid. 
Each of the archives mentioned above is critically important to the story of Swahili. According to Bang, the Zanzibar National Archive holds about 800 manuscripts that include treatises on Islamic disciplines such as law, theology, hadith, figh, grammar, poetry and rhetoric, medicine (herbal and prophetic medicine), magic, astronomy, navigation, and travel accounts. ${ }^{9}$ There are also about 2,60o letters, dating from 1840 s and the reign of Saìd bin Sultan and the latest from the 1940 and the reign of Sayyid Khalifa bin Harub. ${ }^{10}$

Every Swahili document written in 'Ajamī comes in the dialect of its author. Swahili 'Ajamî is not one thing; it is dialectally diverse and its parts have histories that intersect and differ, seldom identical. The utilization of different dialects of Swahili in the literary tradition is in stark contrast to the situation later brought about by the impression that Swahili is one thing and can therefore be written in one way as the promoters of standard dialect emphasize. The many ways in which 'Ajamì documents can be appreciated is what I see as part of the basic characteristics of Swahili 'Ajamī. These characteristics include the engagement of authors and the Arabic script, the freedom to write in any dialect, and how 'Ajami writings reflect the cosmopolitan ethos of the Swahili who, while careful to show piety, have never shied away from writing on secular issues as well.

The 'Ajamī script was the instrument of literacy much in use in all spheres of Swahili life. It was used for drawing up trade and other legal documents, for private correspondence, for genealogies of the ruling families, for writing chronicles of Swahili towns such as Akhbar Pate and the Kilwa Chronicle, for literary works (especially poetry and songs), and for writing religious material. Governance, trade, and diplomacy in Swahili coastal towns and Islands made

9 Anne K. Bang, "Textual Sources on an Islamic African Past: Arabic Material in Zanzibar's National Archive," in The Meanings of Timbuktu, p. 416.

10 According to Bang, "Roughly one-sixth of the collection derives from Sayyid Saīid onesixth from his successors Majid and Khalifa, and one-sixth from Sayyid Barghash. The bulk approximately half - of the collection derives from Sayyid Hammud b. Muhammad and his son and successor 'Alī b. Hammud, that is, from the period 1896-1911. This part of the collection is also the most varied, containing everything from details on expenditure on dinner parties, letters from editors in the Middle East, and notes on the plague to wedding cards and family letters from the Omani branch of the family (including letters from female family members). All in all, the collection is an invaluable source which gives insight into the Bu Sa'id's relations with their East African cadre of bureaucrats and landowners, their subjects, their Indian money lenders, their family in Oman, and not least, with rulers, intellectuals and reformers in Africa, Arabia, and the Middle East." For details, see Bang, ibid, p. 416. 
use of 'Ajamī. The script was also the medium in which artistic representations of experience were recorded, transmitted, and consumed. ${ }^{11}$

As mentioned above a good number of Swahili 'Ajamī documents are bracketed within an Islamic doxology, which encapsulates the understanding that everything depends on Inshä Allah (God willing). The document in Figure 1

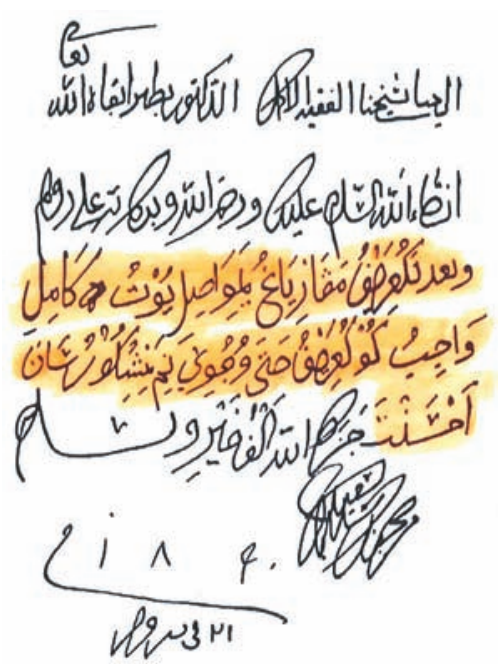

FIGURE 1 Ajamī in Swahili hands SOURCE: BÜTTNER, C. G. (1892) TAFEL XI IN APPENDIX AND PAGE 204
Transliteration and Translation

PREAMBLE

IIa janāb shaykhinā al-faqiyya ila kamāl al-doktoor Bitner abqahu

"To his well-bred, Sheikh, the intelligent, the very perfect, the doctor Buttner."

\section{DOXOLOGY}

Inshä' Allah, assalāmu 'alayka wa raḥma al-llahiwa barakātuhu 'alā

"May the Most High God keep him alive if God wills. Peace be upon you, and the mercy of God, and his blessing."

\section{MESSAGE}

Wa ba'd nakuarifu: Mavazi yangu yamewasili yote kamili; wajibu kukuarifu hatta ujue. Nami nimeshukuru sana, ahsanta. "And after that I am informing you: all my clothes have arrived. It is my duty to let you know. I thank you very much, thank you."

Jazāka Allahu alfu khayr.

"God bless you with a thousandfold happiness."

Wa salām. Min muhabbaka Sulaymān bin Sayyid.

"And greetings. From your beloved Sulaymān son of Sayyid.”

21, Februar 1890.

\footnotetext{
11 Mugane, The Story of Swahili, 2015, p. 177.
} 
is just a simple note to acknowledge receipt of clothes. ${ }^{12}$ The way the text is written represents the typical way in which many Swahili 'Ajamī documents are written. The first two lines are the opening preamble in "pure" Arabic (in italics) "To the well-bred, Shaykh, the intelligent, the very perfect, the doctor Buttner. May God, the Most High, keep him alive.” Then comes the doxology "God willing, peace be upon you, and the mercy of God, and His blessing." This entire structure is in Arabic. Then the message in Swahili is placed in the middle of the note. In Figure 1, the middle two and half lines highlighted in the Arabic and bold in the transcription are in Swahili 'Ajami and the second half of the fifth line is in Arabic as a closing gesture, and a reminder of piety "God bless you with a thousandfold happiness." Then follows the name of the sender and the date of the letter. The example in Figure 1 illustrates the use of 'Ajami in writing mundane things of daily life as one would expect in a literate society. For such notes to exist, writing Swahili in Arabic script was not just done by a small elite but it was a part of life.

From the lowly notes between family, friends, and associates to the very impressive Swahili literary tradition, the pattern is the same: first the preamble, then the doxology followed by the message, and an exit statement emphasizing a belief in God which serves as "a concluding doxology."13 The Utendi wa Mwana Kupona (The Epic of Mwana Kupona) is a case in point. The poem is one of the most celebrated literary pieces of Swahili people. It is famous for the heart-to-heart voice in which it is written. In the poem the author, Mwana $\mathrm{Ku}$ pona binti Mshamu "Mwana Kupona daughter of Mshamu" (1810-60), advises her seventeen-year-old daughter, Mwana Hashima binti Mataka, on a woman's place, roles, duties, and responsibilities with respect to her husband. In the preamble, she calls her daughter to come close and listen:

Negema wangu binti, mchachefu hasanati, upulike wasiyati, asaao asaao kazingatia.

\author{
Come near me, my daughter, \\ do me this little kindness, \\ listen to my last instructions, \\ without delay and follow them.
}

Then the doxology begins with Bismilläh, the familiar Muslim invocation, followed by a very smooth transition from core religious references to tafsir (exegesis of liturgical Islamic text) in Line 6 (highlighted) where she notes that nobody owns ulimwengu "the world." The tafsir is embedded between

\footnotetext{
12 Büttner, C. G. (1892) Suaheli-schriftstücke in Arabischer Schrift Mit Lateinischer Schrift umschrieben Übersetzt und erklärt. Mit xi facsimiletafel. W. Seemann, Stuttgart, Berlin.

13 Ngom, Muslims beyond the Arab World: The Odyssey of 'Ajamī and the Muridiyya, Oxford University Press, 2016, 213.
} 
the verses. The author thus signals that she is a $m j a$ (a sojourner devotee) and proceeds to give the important highlights of her message in lines 12, 13, 14. First in line 12 , she instructs her daughter to stay true to Islam, and to comply with both the obligatory and the optional religious duties. Second in line 13, she instructs her to be well behaved, discreet and edifying. Third in line 14, she asks her to speak the truth to bring blessing to everything she touches and avoid the unjust. The thrust of the message comes early (lines 12, 13, 14) in the 102-verse poem because it will be alluded to throughout ending in a powerful prayer and exhortation. ${ }^{14}$

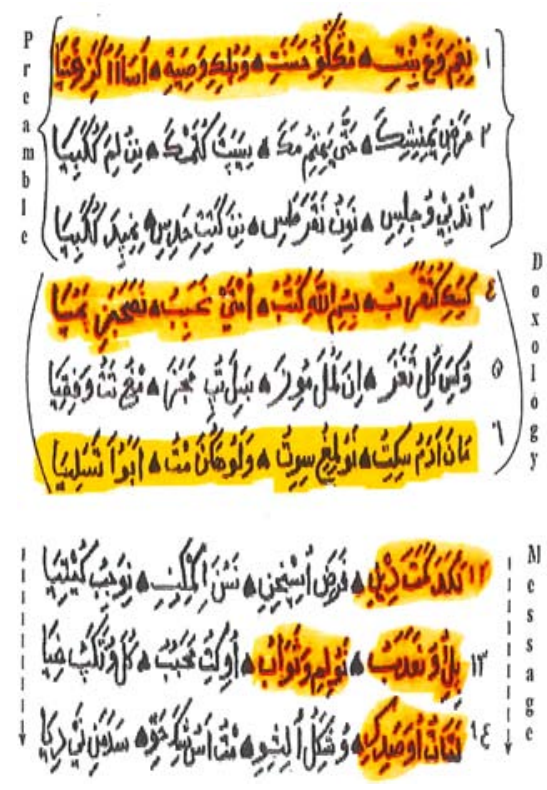

FIGURE 2 Utendiwa Mwana Kupona SOURCE: WERNER, A.

$(1917: 150,151,166) . T H E$ UTENDI OF MWANA KUPONA. ${ }^{15}$
Doxology:

Kwisakwe kutakarabu Bismillah kutubu Now that you are seated beside me write: "In the Name of God" umtae na habibu na sabahaze pamoya obey Him also, the Beloved and his companions.

Mwanadamu si kitu na ulimwengu si wetu The sons of Adam are nothing, and the world is not ours wala hakuna mtu ambaye atasalia nor is there any man who shall remain forever.

\section{Message}

La kwanda kamata dini ...

In the first place hold fast to religion, Pili uwa na adabu na ulimi wa adabu ... in the second place, behave and speak discreetly,

La tatu uwasadiki...

In the third place, speak the truth,

\section{DU 'A' PRAYER}

Verses 67-9o

\footnotetext{
14 The last verse of the epic gives the number of verses as 102. The Mwana Kupona version recorded by Alice Werner has 99 verses written and three left out.

15 Alice Werner, The Utendi of Mwana Kupona, Cambridge, African Department, Peabody Museum, Harvard University, 1917, p. 150, 151, and p. 166. Also see online: https://babel. hathitrust.org/cgi/pt?id=hvd.32044042149120;view=1up;seq=5.
} 
'Ajamì is tied very closely to the Islamic worldview of its faithful - about one third of the Mwana Kupona poem (verses 69 to 102) is a great illustration of a $d u^{(} \bar{a}$, an Islamic prayer followed by a religious evocation addressed to all Islamu (Muslims) and with a general plea to all women in the words somani nyute huramu (read it all Muslim women) everywhere. This type of formulation in writing is what causes Swahili 'Ajamī writings to be called Islamic literature as the notion of Insh $\bar{a}^{3}$ Allah (God willing) is there, either explicitly in the stanzas or implied through oblique referencing.

The personal note is a good illustration of how well one can write Swahili in the Arabic script without modifying it to cater for Bantu phonemes as I explain in the section below. The poem in Figure 2 underscores the fact that the Swahili people have embodied Islamic thought and that their use of 'Ajamī was to deal with their concerns in life and the Arabic script was a tool. Even in the case of the great Swahili tradition of long narrative poetry called Utendi or Utenzi, authorship was not restricted to a group of experts, but rather to literate people in Swahili society like Mwana Kupona binti Mshamu. To say Swahili literature is Islamic is not the same as saying it is therefore Arabic literature. Swahili 'Ajamī does include translated Arabic works into Swahili, but the Swahili literary tradition is not Arabic literature no more than writing in Roman scripts makes the documents Roman. This brings us to the issue of the Arabic script in Swahili scholars' hands.

\section{The Arabic Script in Swahili hands}

There is a limitation to what one can do with the Arabic script without modifications to write a Bantu language, and the intent of introducing the Roman script that the Europeans of the colonial era made a big fuss about, disregarded the developments that were evident in Swahili adaptation of the Arabic script. The European missionary, Bishop Steere, for instance, provided the following rationale in order to signal the need to replace the Arabic script with the Roman Script:

It is absolutely necessary to have a good idea of what you are to read before you can read at all. The reason is that Swahili has five vowels and Arabic only three, and of Swahili consonants the Arabic supplies no means of writing $c h, g, p$, or $v$, nor can consecutive consonants be written without shocking Arabic notions of propriety. Thus, the Swahili are driven to write $b a$ for $p$ and for $m b a$ as well as for $b$; the ghain for g, ng, and $n g$ ' as well as for $g h$; the $f a$ for $v$ and $m v$, as well as for $f$; the $y a$ for $n y$ 
as well as for $y$; the shin for $c h$ as well as sh; and to omit altogether the $n$ before $d, j, y$, and $z$. Initial vowel are only to be expressed by hemzas or 'ains. ${ }^{16}$

In a nutshell, the adaptation of the Arabic script to write Swahili was not easy given that Swahili is forced to use one symbol to represent several different sounds in many cases. The difficulty of writing Swahili in Arabic script is represented in Figure 3 where one Arabic symbol stands for several Swahili phonemes in more than a dozen cases because Swahili has a much larger inventory of phonemes, actual and nuanced, than Arabic.

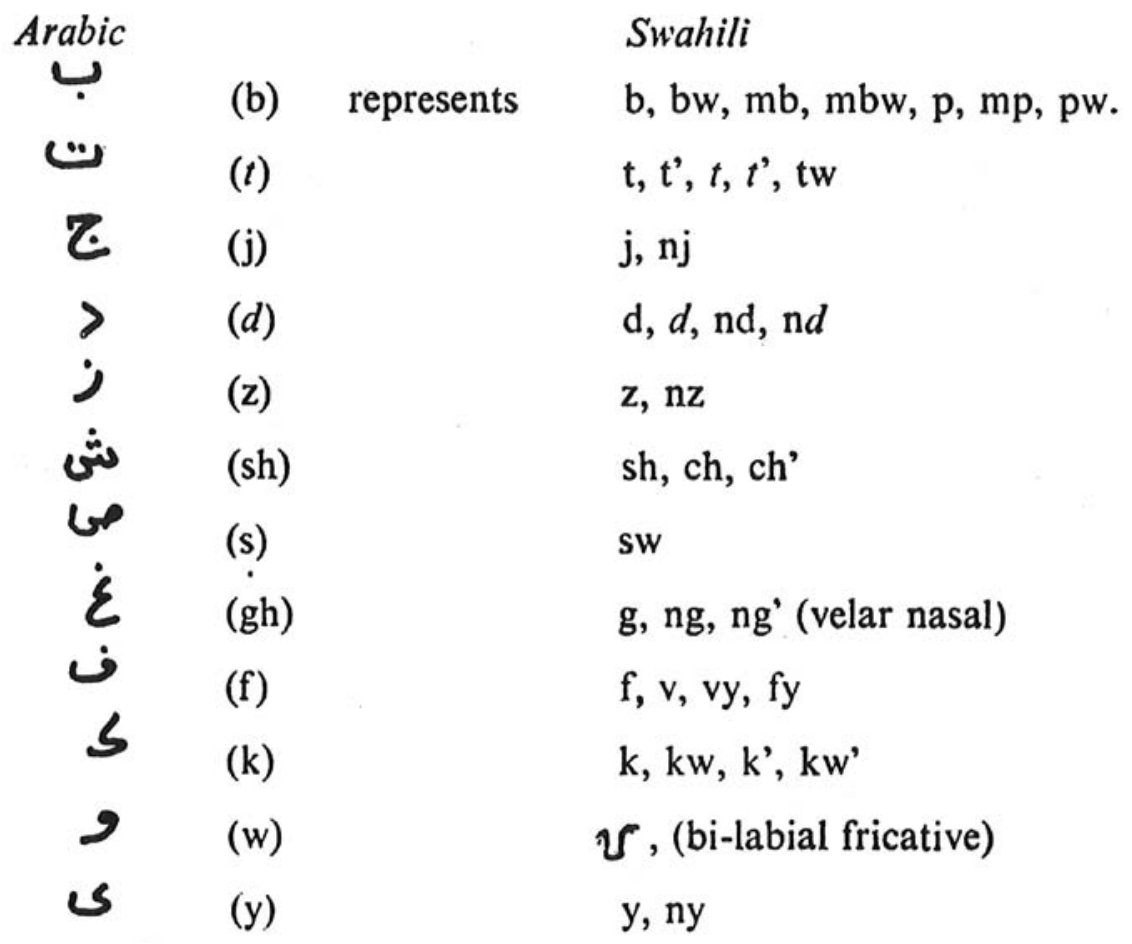

FIGURE 3 Use of Unmodified Arabic letters in Swahili 'Ajamī SOURCE: ABDULAZIZ'S MUYAKA $19^{T H}$ CENTURY SWAHILI POPULAR POETRY, 1994, 70

16 See Edward Steere, A Handbook of the Swahili Language as Spoken at Zanzibar, edited for The Universities Mission to Central Africa, Missionary Bishop for Central Africa, enlarged by A.C. Madan, MA, London, Society for Promoting Christian Knowledge, 1919, pp. 5-6. For an online version, see: https://archive.org/stream/handbookofswahiloostee\#page/n3/ mode/2up. 
Actual because of the differences in important phonemic distinctions in Swahili including $p / b, f / v$, and $c h / s h$ that are critical in Bantu languages, cannot be represented in Arabic script as is given that $p, v$, and $c h$ are absent in the Arabic script as are nasal consonant clusters $m b, m p, n d, n y, n j, n g, n g^{\prime}$ and two vowels $o$ and $e$ (not included in Figure 3). ${ }^{17}$ Nuanced, because there are dialectal differences having to do with sound changes such as $t$ and ch. Additionally, an author in a northern dialect of Swahili, for example, may prefer to make a critical distinction between the Arabic $d(d \bar{a} l, \nu)$, (which is dental for some words especially those borrowed from Arabic), from the Swahili $d$ (which is alveolar for Bantu words) but be unable to do it if strictly adhering to the Arabic script. ${ }^{18}$

To top it off, Bishop Steere gave a 'life and death' example of the seriousness of the lack of the sound $v$ in Arabic and thus its absence in Arabic script to write Swahili.

An instance occurred while I was in Zanzibar of a letter written from Kilwa with the account of a fight, in which it was said that one of the principal men, amekufa, had died, or amevuka, had got away, and which it was no one could certainly tell; the last two consonants were $f a$ and $q a f$, with three dots over them. If two of the dots belonged to the first letter, the man was dead; if two belonged to the next letter, he was alive: but the dots were so equally placed that no one could tell how to divide them. If the Arabic had possessed a $v$, there could have been no mistake. ${ }^{19}$

As we shall see below, Steere's kind of depiction had a script liberation agenda that ignored the progress underway in 'Ajamī writing, giving the impression that the script was static and hopeless.

The personal note in Figure 1 is a good illustration of how well one can write Swahili in the Arabic script with so little modification. The fă' used to represent $\mathrm{v}$ has three dots above it in figure 1 - the only modification in the note. Mwana Kupona's poem is also a good illustration of how the script can be enriched to better represent Bantu sounds. In the 'Ajamī texts with no modification of Arabic script, Swahili is accommodated into the Arabic by making use of the script available and adding dots "without shocking Arabic notions of propriety," to use Steere's words. The adoption of the script was not to communicate to the reader a blind adherence to Arabic script. As we shall

17 Note that I am generally using the standard Swahili Latin script orthography rather than symbols from the International Phonetic Alphabet (IPA), which I use only in one exceptional case for clarity.

18 For further details, see Mugane, The Story of Swahili, p. 185.

19 Steere, ibid., p. 6. 
see below, the instinct to enrich 'Ajamī in order to fully accommodate Bantu sounds was robust.

\section{Writing Swahili 'Ajamī with the modified Arabic Script}

There has been a long tradition of writing religious content without expanding the script that has produced some of the most outstanding literary pieces in Swahili. The following is an illustration from the famous Utenzi wa Shufaka (Poem of Mercifulness) a poem of 285 stanzas consisting of four lines of eightsyllables each written in Arabic script without any effort to adjust or add diacritics to the script to make it adequate to write Swahili. This is a narrative poem. It is about angels Gabriel and Michael's visit to earth to investigate whether compassion and kindness were still attributes found amongst humans. Michael thought none were left but Gabriel disagreed. After spending time interacting with humans, the two left satisfied that compassion was still among the living. Utenzi wa Shufaka is written in an old Swahili variety spoken in Pate - one that resembles inland Bantu languages. This narrative poem was "enormously popular especially among Swahili women." ${ }^{20}$ The poem is an example of a document written in Arabic script in which one Arabic letter stands for more than one phonemic sound. ${ }^{21}$ The sounds $p, v, n d, m b, m p, n g$, and $n y$, are not in Arabic.

$p$ written as $\left(b \bar{a}^{\supset}\right)$, Shufaka, line 147

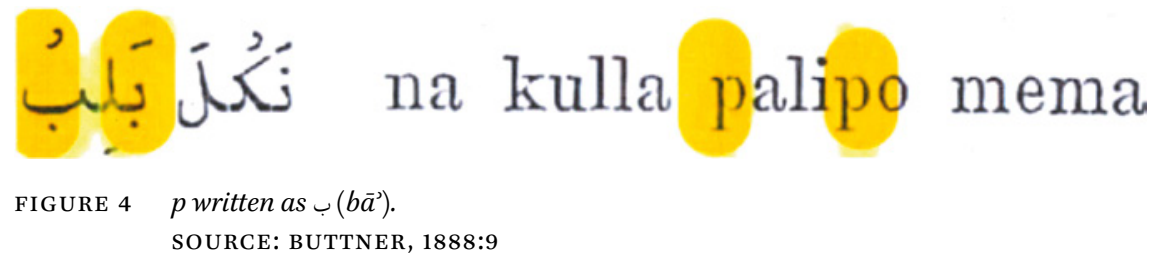

$m b$ written as ب, Shufaka, line 150

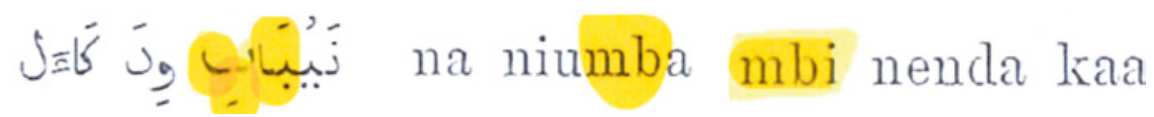

FIGURE 5 mbwrittenas $4\left(b \bar{a}^{\top}\right)$.

SOURCE: BUTTNER, 1888:9

$20 \quad$ Alice Werner, "Moslem Literature in Swahili", The Moslem World, 10 (1920), p. 29.

21 For similar processes in West Africa, see Lameen Souag, "Ajami in West Africa", Afrikanistik online, http://www.afrikanistik-online.de/archiv/2010/2957; and Fallou Ngom, "Ajami Script in the Senegalese Speech Community," Journal of Arabic and Islam Studies, 10/1 (2010), pp. 1-23. 
$n g$ written as $\dot{\dot{\Sigma}}$ (Ghayn $\dot{\text { ) }}$ word-initially, Shufaka, line 148

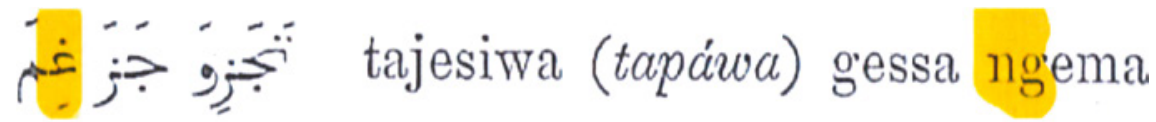

FIGURE 6 ng written as Ghayn word-initially SOURCE: BUTTNER, 1888:9

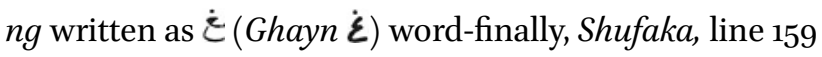

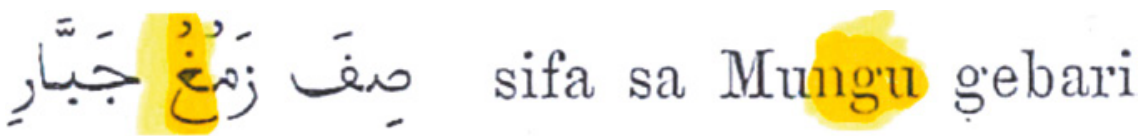

FIGURE 7 ng written as Ghayn word-finally SOURCE: BUTTNER, 1888:9

$v$ written as $\boldsymbol{ن}(f \bar{a})$, Shufaka, line 149

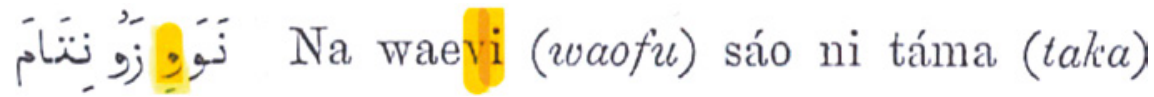
FIGURE $8 \quad v$ written as $\left(f \bar{a}^{\prime}\right)$ SOURCE: BUTTNER, 1888:9

$n d$ written as $>(d \bar{a} l)$, Shufaka, line $15^{1}$

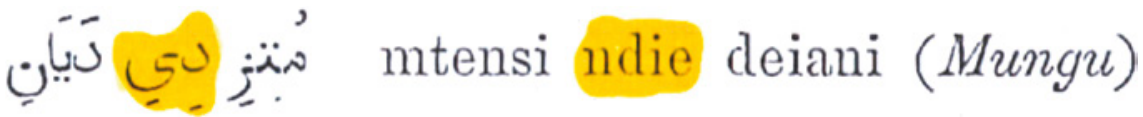

FIGURE 9 ndwritten as $($ dāl $)$

SOURCE: BUTTNER, 1888:9

ny written as $(y \bar{a})$ Shufaka, line 362

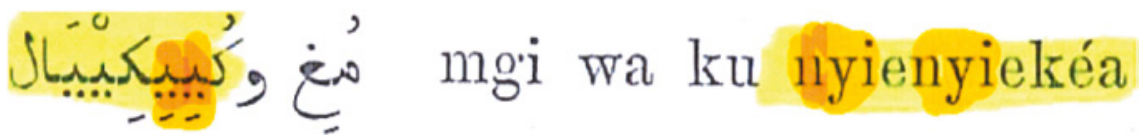

FIGURE 10 nywritten as $\left(y \bar{a}^{\prime}\right)$

SOURCE: BUTTNER, 1888:18

SOURCE OF THESE EXAMPLES: BUTTNER C.G., "UTENZI WA SHUFAKA," IN ZEITSCHRIFT FUR AFRIKANISCHE SPRACHEN, BERLIN, VERLAG, 1888. 


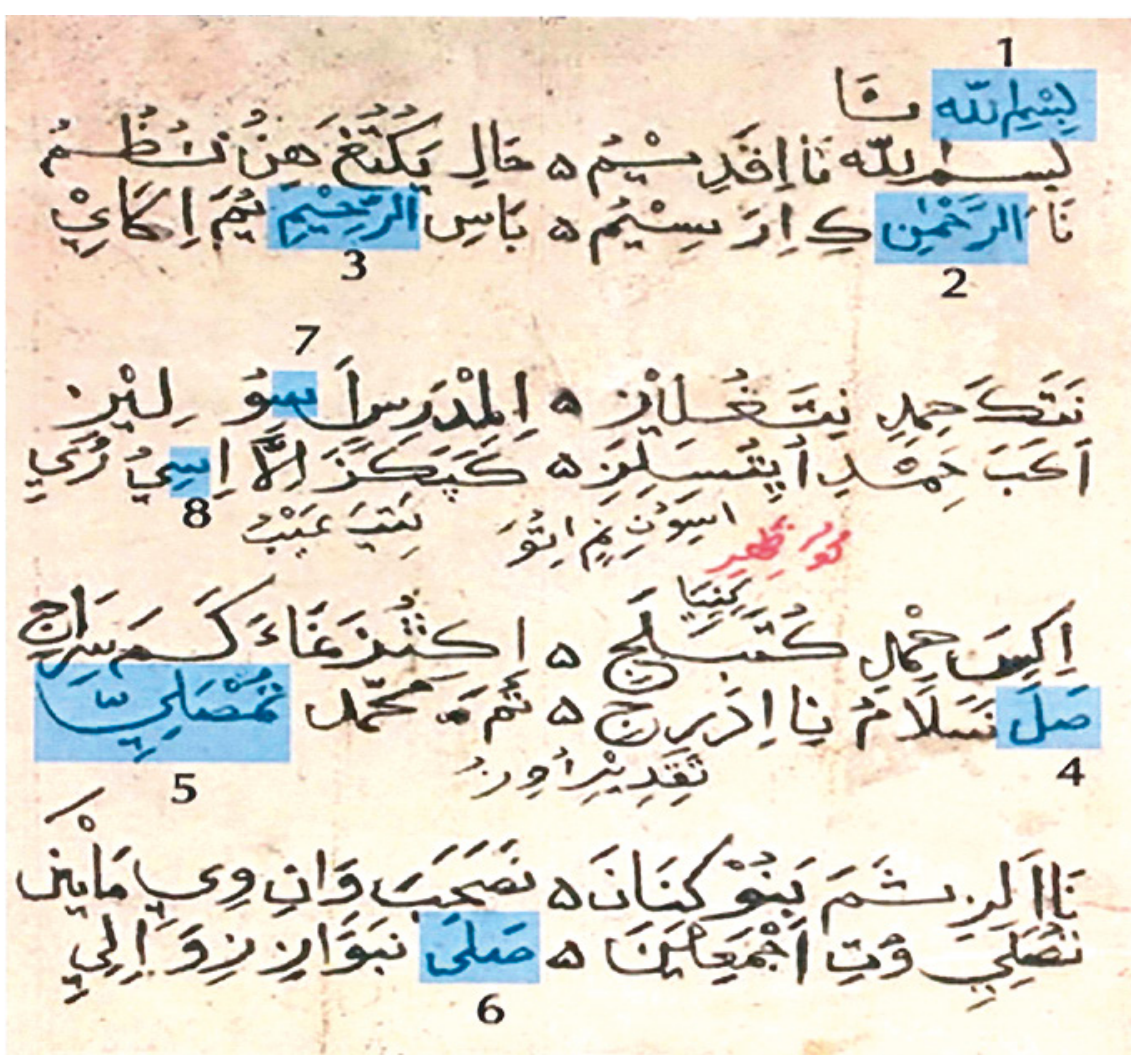

FIGURE 11 First four stanzas of al-Inkishafi, a poem by Sayyid Abdalla bin Ali bin Nasir, ca. 1800. SOURCE: ABDALLAH BIN ALI BIN NASIR, AL-INKISHAFI [CATECHISM OF A SOUL], 1977 NAIROBI, EAST AFRICAN LITERATURE BUREAU.

This tradition of writing in unmodified Arabic script is often a hallmark of religious documents. The poem in Figure 11 below is a piece of the famous alInkishafi - a poem written by Abdalla bin Ali bin Nasir. ${ }^{22}$ It is a warning about divine retribution for those who live a life of hubris and exhorts people to put no trust in the earthly world. ${ }^{23}$ This is a poem that the Swahili people have "found to be a source of great consolation in all sorts of contexts, including in the case of the person who smuggled a copy into Zanzibar's jail when he was incarcerated by the colonial regime." ${ }^{24}$ According to James de Vere Allen,

\footnotetext{
22 James de Vere Allen, Al-Inkishafi, Catechism of a Soul: Translation of Al-Inkishafi by Abdallah bin Ali bin Nasir, Nairobi, East African Literature Bureau (1977).

23 Ibid., p.18.

24 Ibid., p. 22.
} 
another unnamed person believed that the poem saved his sanity only by reciting the sections he could remember when he was in the same jail after the 1964 Revolution. ${ }^{25}$ Yet another man who had a breakdown after he went bankrupt and and later partly recovered often read the poem to himself in a mosque or at night. Many more people find solace in times of hardship in the poem. ${ }^{26}$ Living up to its promise, the poem ends with a supreme irony, making its point again ("to put no trust in the earthly world") in that the author himself is "cheated" by death and does not live long enough to finish it.

The al-Inkishafi part in Figure 11 shows the strong Islamic influence. It starts with Bismilläh (In the Name of God), as do most Muslim texts (see \# 1). It also references the Names of God as reflected in al-Rahmān (The Most Merciful) and al-Rahim (The Most Beneficient) shown in \# 2 and 3 respectively. It is evident that not only are some key words drawn directly from Islamic religious texts in Arabic, some idiosyncratic Arabic letters are also taken as well. For example, in Swahili there is no emphatic ș sound represented by the letter صin Arabic. The writer uses the letter w exclusively for the $s$ sound (seen in \# 7 and 8). However, the letter ص still appears in the Arabic words in \# 4,5, and 6, which share the trilateral root for 'pray' (ș-l-w, șād, lām, and wāw), even though the is pronounced in the same manner as $\mathrm{m}$ in Swahili.

In Figure 11, the use of $ص$, which is not necessary in Swahili, is incorporated in writing, thus reflecting the Islamization of Swahili. For example, the Arabic word șalät (prayer) is more used by Muslims than Christians who seem to prefer kuomba/maombi (praying/prayer), which is Bantu. But the Islam encoded in Arabic did not stop the writing of parts of the Swahili bible in 'Ajamī as the examples in Figure 12 show.

In the title Injiliya Luka in A of Figure 12, we see that $k a$ is written with $q q \bar{a} f$, which is absent in Swahili, and all $n g$ in B and D are represented by ghayn just as in the Shufaka epic. The word aya (from aya, verse in Arabic) in C is an Islamic reference drawn from the Qur'än. The fact that the word is used for the Bible reflects a theological dimension of Ajamization, the mixing of symbols and referents of Islam and Christianity. But Kijuma who transcribed it had some unconventional views. In one of his poem Nasara wa Arabu, Kijuma shows his cosmopolitan outlook when he observes that the monotheistic religions known to him were like "ships each one having a different captain, Mūsā (Moses), 'Isā') (Jesus) and Muhammad, but all of them heading towards the same port, while the passengers of each ship consider themselves to be the chosen ones, sending the others to hell." Little wonder then that he was even

25 Ibid.

26 Ibid. 


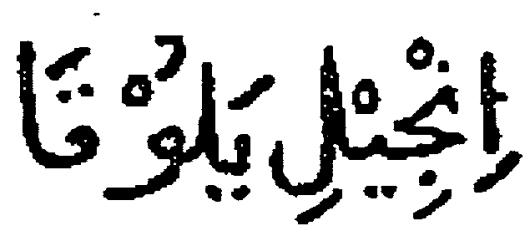

A. Injili ya Luka "The Gospel of Luke" SOURCE: SWAHILI BIBLE 1893-INJILI YA LUKA27

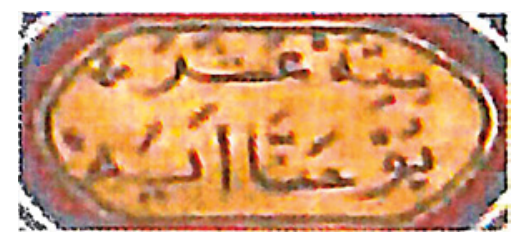

C. Sitiashara Yohana aya "Verse sixteen"28 SOURCE: MUHAMADI KIJUMA, ET AL. (2010:532)

FIgURE 12 Biblical text in Ajamī

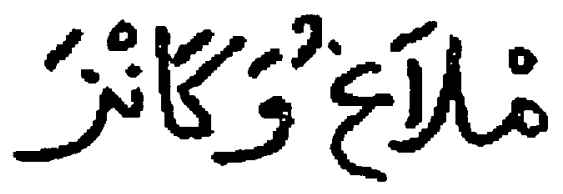

B. Mlango wa Kwanza "The First Chapter" SOURCE: SWAHILI BIBLE 1893-INJILI YA LUKA

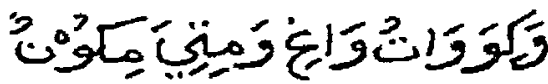

D. kwa kuwa watu wengi wametia mikono ....

For as much as many have take in hand .... SOURCE: SWAHILI BIBLE 1893-INJILI YA LUKA

reported to have had a nickname Masihii (Messiah in Swahili) to indicate his alleged conversion to Christianity. Kijuma used the word ayya not fungu (verse) which with time became the distinguishing Christian convention of referring to Bible verses. ${ }^{29}$ Aya is the Swahili word for paragraph.

Figure 13 is a carving of John 3:16 on wood as part of a door frame. Part A being is at the top of the frame, and Part B at the bottom. The images in Figure 13 are part of the work of Muhamadi Kijuma who was the literal embodiment of 'Ajamī expertise on paper and beyond into the arts. He was a calligrapher, painter, designer, poet, scribe, commentator, teacher of foreigners, and an icon of the Swahili literary tradition. ${ }^{30}$ Kijuma and others like him were the masterminds of the twentieth -century Swahili 'Ajamī tradition.

\footnotetext{
27 William Ernest Taylor (translator), Swahili Bible-Injili ya Luka: The Gospel of St. Luke in Swahili as spoken at Mombasa, London, British and Foreign Bible Society, 1893.

28 Muhamadi Kijuma, Gudrun Miehe, W. Hichens, Clarissa Vierke, Sauda A. Barwani, Ahmed Sheikh Nabhany, and Ernst Dammann, Muhamadi Kijuma: Texts from the Dammann Papers and Other Collections, Cologne, Germany, Koppe, 2010, p. $5^{0 .}$

29 Ibid.

3o Mugane, The Story of Swahili, 2015, pp. 160-161.
} 


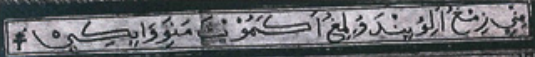

A

Mwenyezi Mungu aliupenda ulimwengu akamweta mwanawe wa pekee

For God so loved the world that he sent his one and only Son

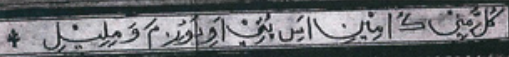

B

kula mwenye kuamini asipotee, awe na uzima wa milele

that whoever believes in him shall not perish but have eternal life.

SOURCE: MUHAMADI KIJUMA, ET AL. (2010:532)

FIGURE 13 Image of the Bible book of John 3:16 by Muhamadi Kijuma

\section{'Ajamī As Enrichment by Modification of the Arabic Script}

Turning to the modified Arabic letters in Swahili 'Ajamī writing, consider Figure 14. It is not the case that authors wrote in one way. We find works by the same author in both the modified and the unmodified scripts. Two thirds of Muyaka bin Haji's poetry, for instance, is written in the script without modification, and about a third with a thoroughly modified script. ${ }^{31}$ In the examples that follow in Figure 14, we see how some tinkering with the Arabic script produced an efficient way of writing Swahili.

As seen in Figure 14, ch is presented as w with kāf $s$ on top as indicated in A and $\mathrm{H}$, the $t w$ and $k w$ in $\mathrm{G}$ and $\mathrm{J}$ are respectively rendered as $t$ and $k$ with a diacritical $w \bar{a} w$. The combination of $m$ and $b$ as in the phoneme mba in wakumba in $\mathrm{B}$, which is non-existent in Arabic, is written by placing the $\operatorname{mim}(m$ or $p$ ) on top of the $b(ب)$ at the end of the word, perhaps to indicate that $m b$ sound is really $b$ with a prenasalizing $m .^{32}$ Thus, the $b$ sound has the $m$ placed above it because $\operatorname{mim}$ is in the service of $b$ in the formation of $m b$ and not vice versa. Then just as in Arabic, the short $a$ vowel or fatha is pronounced. Thus, the final syllable in the word is pronounced as $m-b-a$. The word mafungu in C

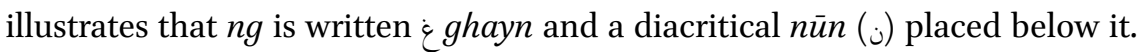
Here again we see $\dot{\varepsilon}$ represents $g$ and that $i$ is in service of modifying (prenazalizing) the $g$ just as in the case of $m b$ just mentioned. Similarly the word

31 Abdulaziz Mohamed H, Muyaka, 19th Century Swahili Popular Poetry, Nairobi, Kenya Literature Bureau, 1979, reproduced in 1994, p. 72.

32 Prenasalization refers to the pronunciation of a stop sound (p, b, d, and $g$ in Swahili) with a brief interval of nasalization. 


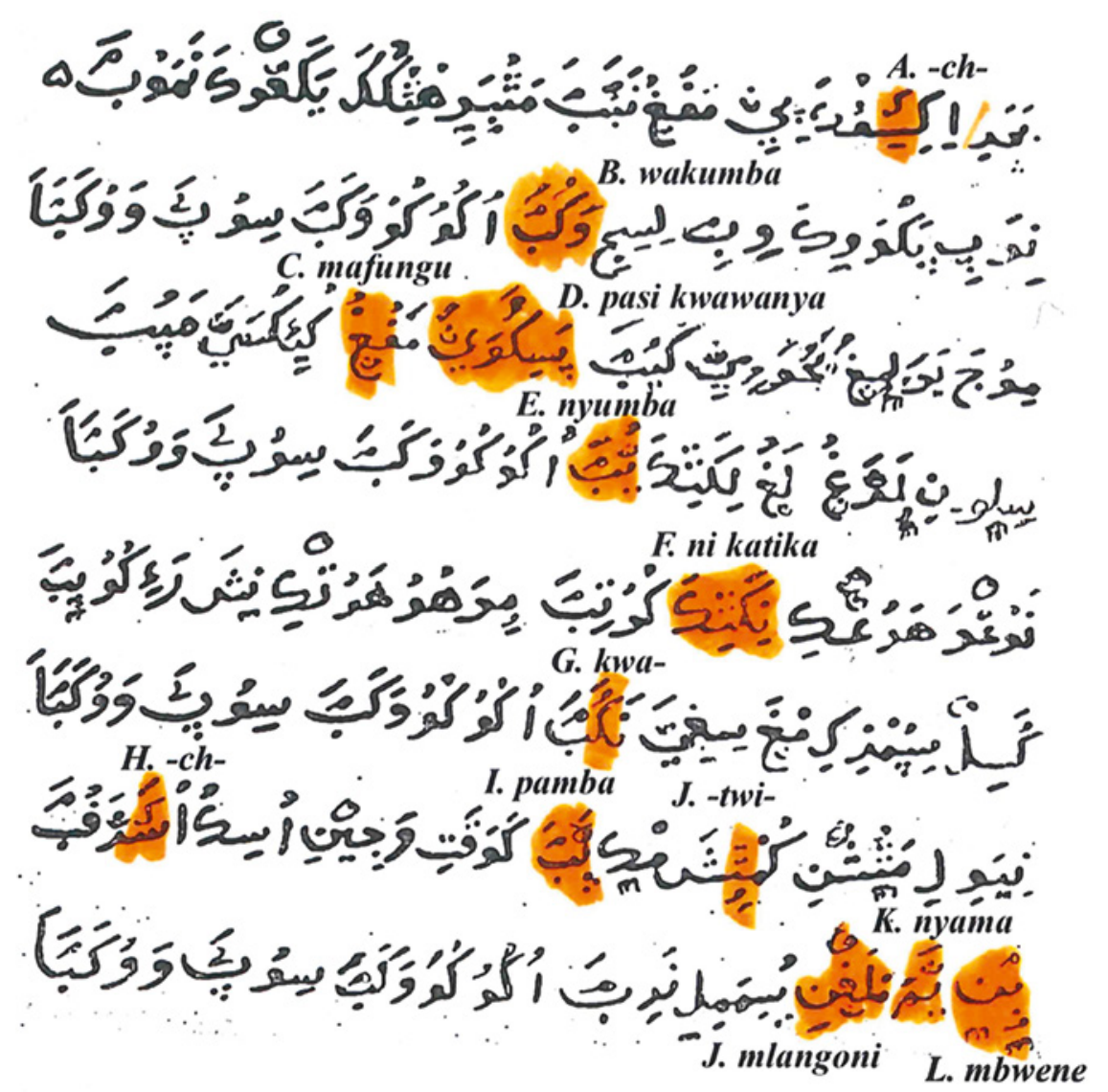

FIGURE 14 Mwalimu Sikujua's representation of nasals and $\mathrm{ch}$, tw and $\mathrm{kw}$ in Swahili Ajami SOURCE: ABDULAZIZ MOHAMED H MUYAKA, $19^{T H}$ CENTURY SWAHILI POPULAR POETRY, NAIROBI, KENYA LITERATURE BUREAU, 1979, REPRODUCED IN 1994, P. 73 .

mlangoni in J, the second to last letter, \& ghayn carries with it a diacritical below and a new symbol $\mathcal{O}$ for the $o$ sound. The $\dot{u}$ below $\dot{\varepsilon}$ indicates that $g$ should be construed as the prenazalized $n g$. Next the new vowel, $\mathcal{O}$, indicates the $o$ sound pronounced after the $n g$. Thus the reading of $n g o$ is from the bottom going up.

With regards to D in Figure 14, the word pasi kwawanya has modified letters to represent Swahili $p, k w$, and $n y$ sounds. To read the word pasi kwawanya, first the three dots underneath the first letter indicates it is a $p$ sound with a fatha on top, which indicates that this structure is pronounced $p a$. In the middle of the word the $s$ (kâf) has a damma (for the $u$ or $w$ sound) above it, 
which indicates that the $w$ sound must follow the $k$ sound. With the addition of the short vowel $a$ on top (fatha), this middle sound is pronounced $k w a$. In writing $n y$, the last letter $y y \vec{a}$ (which represents the $y$ sound) has a diacritical $n \bar{u} n$ above it, which indicates that the $n$ sound is to be pronounced before the $y$ because it is $y$ that is being nasalized, not $n$ being added to $y$. With the fatha again on top, the final pronunciation is nya.

Reading nyumba in E, the first letter $(y \bar{a})$ again has a diacritical $ن$ placed above it, indicating the $n y$ sound. This time it has a damma on top of it, creating the pronunciation $n y u$. The next letter, 4 (representing the $b$ sound) has a (carrying the $m$ sound) on top along with the fatha, resulting in $m b a$. Thus, the whole word is pronounced as nyu-mba. Reading ni katika labeled F, the four dots above the tooth is an introduced symbol that represents the alveolar $t$ sound. The kasra beneath it represents the short $i$ sound. With regards to the word pamba in I, the focus here is on the representation of $p$. The first letter of the first word begins with the tooth with three dots underneath which represent the $p$ sound, as seen in Pasikwawanya above. However the added symbol, $\boldsymbol{\gamma}$, indicates that the $p$ sound is aspirated $\left(\left[\mathrm{p}^{\mathrm{h}}\right]\right)$. When combined with the Fatha on top and followed by the familiar $m b a$ combination discussed above, the word is pronounced as p'amba (or [ $\left.p^{h} a m b a\right]$ phonetically).

The word mbwene in L, has a above the, , a below it, and the new innovation, $m$, below them all. The on top indicates the pronunciation of $m$ before the pronunciation of $b$. Next, the below the line indicates the pronunciation of $w$ comes after the $b$, and the $\pi$ on the bottom indicates the pronunciation of $e$ comes after the $w$. Thus the first syllable is pronounced as mbwe. The next letter,, also has the vowel $m$ introduced below it, indicating the pronunciation $n e$, thus completing the word mbwene.

Writing Swahili in Arabic script exists in two forms as noted earlier. One is the use of Arabic script without modification and the other with modification of the script - both of them entail enriching 'Ajamization processes. Between the two forms of writing Swahili with the Arabic script there is some latitude. As shown above, the text in Figure 1 is written with only one letter modification. However, in Line 1 of Mwana Kupona (Figure 15) the sound $n g$ in wangu is represented by $\dot{\varepsilon}$ (ghayn). Ch in 2 of Figure 15 is a modified $ت$ (Arabic $k$ ) with two dots added as seen in the word mchachefu. The sound $p$ is a modified with two dots added below as seen in example 3 .

From this first line in Mwana Kupona we see the attempt to disambiguate the use of $c h$ and $p$ but not representing the prenasalization in $n g, n j$ and $m b$. Thus this particular rendition of Mwana Kupona is a case of moderate modification where only a few letters are affected. But more important in this paper 


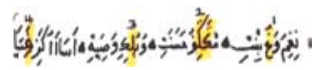

Negema wangu binti, mchachefu hasanati, upulike wasiyati asaao kazingatia Come near me, my daughter, do me this little kindness, listen to my last instructions without delay and follow them.

FIGURE 15 First Stanza of the poem Mwana Kupona

is that the enrichment of the script was a choice of writers who were deeply engaged in the marketplace of ideas and writing.

The first line (Figure 16) of the famous Wimbo wa Dhiki (Song of Agony) ${ }^{33}$ also known as the Jail Song by Fumo Liyongo wa Bauri ${ }^{34}$ instantiates another style of writing Swahili with partial adaptation of the Arabic script. Here we see the writing presents $m b$ only as $b=$ and $n g$ with \& ghayn only. Yet the modifications for alveolar $t$ Gand the vowel $e \pi$ are entertained in the copy shown in Figure 16.

Liyongo's life story shows the continuities between the Swahili city-states and inland peoples. Liyongo was comfortable both in the cities and as well as the Nyika (rural hinterland), among the Pokomo and Oromo as well as among the Watwa and Boni hunter-gatherers. Much like many Africans, his social network flowed seamlessly between the Swahili city-states and the Nyika, between Muslim country and non-Muslim world of the interior. The hinterland off the

33 There is undisputed dominance of song genre in Swahili literature. Knappert records twenty-five kinds of songs: songs of dance, love, songs for children, songs for women, philosophical songs, proverb songs, work songs, songs for coconut cultivation, travelers' songs, sailors-fishermen-boatmen's songs, prayer songs, message songs, praise songs, songs of defiance and mockery, battle songs, songs of secrets (rhyming riddles), political songs, wedding songs, the Ghazal, the Serenade, the songs of Binti Saad, songs with allusions, curse songs, and Taarabu songs. The variety of songs in oral form far surpasses those available in written form. Many of these songs were performed for centuries before being transcribed in 'Ajamī. See Jan Knappert, A Survey of Swahili Songs with English translations, Lewiston, New York, Edwin Mellen Press, 2004.

34 Fumo Liyongo, the best-known Swahili poet, is believed to have lived somewhere between the thirteenth and the seventeenth centuries. Liyongo is remembered for his lyrics for the gungu dance. Gungu songs have lines of ten syllables each, with a caesura on the fourth syllable. Liyongo's songs transcribed in 'Ajamī are available in Taasisiya Uchunguzi wa Kiswahili, Nyimbo za Liyongo-Liyongo Songs: Poems attributed to Fumo Liyongo, collected by The Liyongo Working Group and edited by G. Miehe, A. Abdalla, A.N.J. Bhalo, A. Nabahany, A. Baschiera. C. Dittemer, F. Topan, M.H. Abdulaziz, S.A.M. Khamis, Y.A. Omar, and Z.M.F. Al-Bakary. Dar es Salaam, TU KI, 2006. 


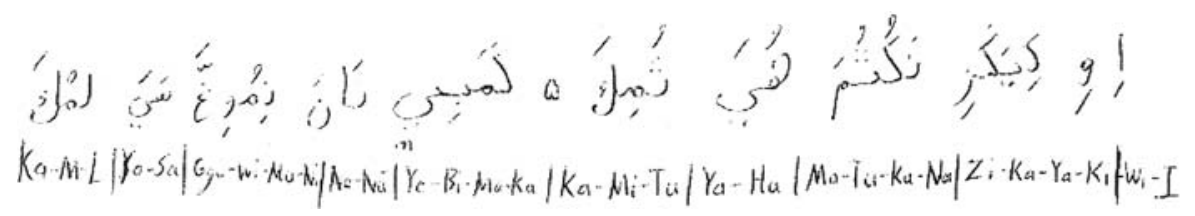

Ewe Kijakazi Nakutuma Hujatumika kamwambie mama ni muinga sajalimuka You maid, I sent you. You still don't understand. Tell my mother who still is ignorant.

FIGURE 16 First line of Wimbo wa Dhiki by Fumo Liyongo wa Bauri SOURCE: TAASISI YA UCHUNGUZI WA KISWAHILI (TUKI) $2006 . .^{35}$

east coast of Africa was part of the subject matter of 'Ajamī writings. Thus, the kinds of songs associated with Liyongo, which are gungu songs sang at weddings and other important occasions, bear heavy influences from inland traditions. With regards to the written and oral tradition, 'Ajamì compels us to view Swahili historical lands as integral not distinct to the hinterland. This is why Liyongo is remembered as a hero among the Pokomo an inland Bantu people further north (from Swahililand) along the River Tana. ${ }^{36}$ The inlanders were seamlessly connected to the east coast of Africa for centuries in much the same way we find them in the Swahili society of the seventeenth century onwards. The difficulties encountered with the Arabic script were not the handicap European scholarship turned it to be.

Figure 17 shows the innovative solutions of Swahili writers to address the limitations of the Arabic script. These solutions reflect orthographic enrichment processes (i.e. orthographic 'Ajamization processes). I have already discussed some of these processes.

The levels of difficulty in writing Swahili with the Arabic script compared to the Roman script is not a compelling argument for a change to the latter as the colonial era Europeans made it to be. Swahili 'Ajamī may have gone underground, but it is still in use in the horizontal sphere. The examples I have discussed in this article have shown the development of Swahili 'Ajamī tradition and its functions before a new Eurocentric literacy imposed a new script and returned 'Ajamì back to the Mosque and private forums. I now conclude the paper with what I started: How Swahili 'Ajamists were rendered voiceless.

35 Taasisiya Uchunguzi wa Kiswahili, 2006.

36 Jan Knappert, A Survey of Swahili Islamic Epic Sagas, Lewiston, New York, Edwin Mellen Press, 1999, pp. 96-97. 


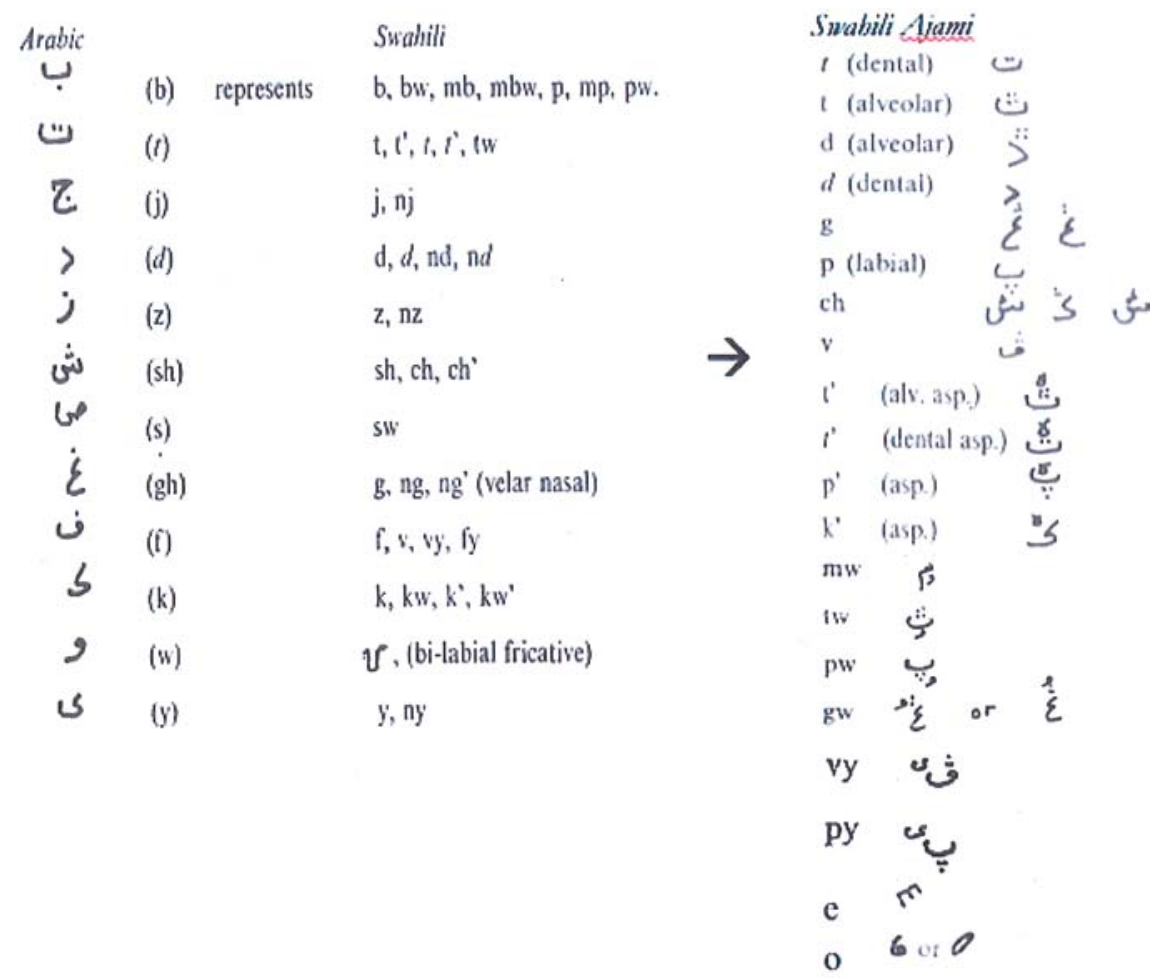

FIGURE 17 Solution for phonemic representation as presented in Mwalimu Sikujua's copy. Mwalimu Sikujua's 188os 'Ajamī representation of one third of Muyaka bin Haji (1776-1840) poetry. SOURCE: ABDULAZIZ MOHAMED H MUYAKA, $19^{\text {TH }}$ CENTURY SWAHILI POPULAR POETRY, NAIROBI, KENYA LITERATURE BUREAU, 1979, REPRODUCED IN 1994, P. 70.

\section{Conclusion}

The 'Ajamī record in Swahili like all others in Africa is a library consisting of unpublished manuscripts, booklets, poetry, essays, treatises, travelogues, private letters and business records spanning generations, health information and numerous other documents classifiable in multiple categories. It is therefore a library of African thought in motion. Mwana Kupona did not, for instance, write her only poem by the same name to advance 'Ajamī. It was because she had to pour out her heart to her daughter in writing so that she could retreat to 
it throughout her life, if not learn it by heart and share it with Muslim women. Thus the power of writing in one's vernacular language comes through. The poem has no doubt been a guide to other daughters of Swahili to wise up to life. As Mwana Kupona wrote her poem, we gained an inside look at how the society was organized and what constituted success. In the process of looking, we hear the words of Pate Swahili, which immediately give us the cultural and linguistic orientation of the "Bantu-ness" of Swahili that Nurse and Hinnebusch have written about. ${ }^{37}$ 'Ajamī writings are for the living; they do not imitate life - they are life, they live it and life is not uniformity and conformity; it is social engagement. Ajamī gives freedom to the writer to write in the vernacular, the way they speak not the approved way of speaking. This is why the use of Kiunguja as standard Swahili has managed to keep the literatures of other dialects out of view. 'Ajamī literature calls for proficiency in African languages for without it they are bound to remain inaccessible. The 'Ajamì library has yet to be mined by African studies.

The odyssey of 'Ajamì in Swahili, just like the odyssey of Ajamì among the Wolof that Ngom documents in Muslims beyond the Arab World: the Odyssey of 'Ajami and the Muridiyya (2016) and others, is illustrative of the historical ties of many Africans to Islam, trade, and cosmopolitanism. Yes, Europhone African writers and Africanists may see themselves as the leaders of intellectual production on Africa, but there is a whole other universe that is often completely absent in the formulation of African studies - that of a writing tradition in non-Roman scripts in Africa. In the case of Muslim Africa and its surroundings there is a very old tradition of writing in 'Ajamī as Ngom (2016) has shown on West Africa and Mugane (2015) has discussed with regards to Africa's Swahili speaking region. In East Africa, we find a centuries-old Swahili literary canon that is available to the world through transliteration and translation as Europeans of the colonial era supervised in the process of changing the Arabic-based script to a Roman alphabet in part to "de-Arabize" and therefore "de-Islamize" Swahili.

When the Europeans laid their hands on the Swahili 'Ajamì documents, cataloguing them and placing them in libraries, the script owner's importance waned. Bitter is the way the Swahili 'Ajamì has been transliterated to oblivion by which I mean there is no real requirement that compels contemporary Western-trained Swahili scholars (especially in Africa) to even study

37 Derek Nurse and Thomas J. Hinnebusch, Swahili and Sabaki: A Linguistic History, Berkeley, Los Angeles, 1993. 
the Swahili manuscripts written in Arabic script (both Arabic and 'Ajamī). As Vierke puts it, "in the course of the twentieth century, Swahili in Arabic script was preserved and commented on in published editions of texts and became part of a European academic tradition and an established branch of philology, while it gradually lost its importance in Eastern Africa. There have been more critical editions and publications of Swahili text in Arabic script in Europe than in Africa." ${ }^{38}$ What it means to have the core Swahili authorship going by the labels the Taylor Papers, Hichens Collection, Werner Collection, Knappert Collection, Whiteley Collection, and Allen Collection and so forth, which are mostly located in European universities in England, Germany, Belgium and the like, is a riddle that invites the kind of scrutiny that Biersteker and Plane touched on as to how we do Africa related academic work more generally. It is not clear who were the analysts and interpreters and who were the scribes. It was Muhamadi Kijuma who recalled, authored, and interpreted many documents. Mwalimu Sikujua wrote copies of Muyaka's poetry, and Mwana Kupona spoke the meaning of her poem to Alice Werner. Yet, the translator of the documents into English, French and German are the icons of the Swahili 'Ajamī literary tradition. ${ }^{39}$

There were many other Swahili men and women who harbored the manuscripts and were often forthcoming with elaborations and explanations as "informant contributors" to Taylor, Knappert, Buttner, Steere, Lambert, and others, who are the recognized experts. It is instructive that Kijuma was the pedagogical genius who taught Lambert how to compose Swahili poetry, which made "him the only European to have written and published Swahili poetry acceptable to the Swahili people." 40 Yet, Hichens has a collection and Ernst Damman, another student of Kijuma, is termed "the greatest living expert on Swahili poetry" of his day. ${ }^{41}$ How Swahili 'Ajamī scholarship dwindled

38 Clarissa Vierke, On the Poetics of the Utendi: A Critical Edition of the Nineteenth-century Poetry, LIT Verlag, 2014, p. 325.

39 Ann Biersteker and Plane Mark, "Swahili Manuscripts and the Study of Swahili Literature", Research in African Literatures, 20/ 3 (1989), pp. 449-47.

40 See Kijuma et al., 2010; and P.J.L. Frankl, "H. E. Lambert (1893-1967): Swahili Scholar of Eminence (Being a Short Biography together with a Bibliography of his Published Work)", Journal of African Cultural Studies, 12/1 (1999), pp. 47-53.

41 Jan Knappert, "Eine Suahelidichtung des Sheikhs Muhammed bin Abubekr bin Omar Kidjumwa Masihii über Jesus by Ernst Dammann", Journal of Religion in Africa, 12/2 (1981), p. 157 . 
in its homeland and went to Europe remains one of the lingering puzzles in the odyssey of 'Ajamī. Also still to be told in that odyssey is the role Swahili women have played in manuscript production, storage, and interpretation. ${ }^{42}$

42 See Joseph L. Mbele, "Wimbo wa Miti: An Example of Swahili Women's Poetry”, African Languages and Cultures, 9/1 (1996), pp. 71-82. 